\title{
Dainius Žalimas
}

Katedra Prawa Publicznego

Uniwersytet Wileński

\section{WIECZYSTE POSTANOWIENIA KONSTYTUCYJNE PODSTAWĄ DEMOKRATYCZNEJ TOŻSAMOŚCI KONSTYTUCYJNEJ}

W 2014 roku oficjalna doktryna konstytucyjna Republiki Litewskiej przeszła dość radykalną transformację; rozpatrując sprawy dotyczące konstytucyjności ${ }^{1}$ poprawek do Konstytucji i organizacji ${ }^{2}$ referendów, Sąd Konstytucyjny sformułował doktrynę materialnych i procesowych ograniczeń zmian Konstytucji. W zakresie, w jakim dotyczy to materialnych ograniczeń zmian Konstytucji, oznaczających określone wymogi co do treści poprawek, nieuchronnie powstaje problem hierarchii postanowień Konstytucji. Uznając bowiem takie ograniczenia, należy uznać również istnienie pewnych fundamentalnych postanowień konstytucyjnych, do których należy dostosowywać treść poprawek do Konstytucji. A skoro tak, to w jaki sposób można dokonać zmiany takich właśnie postanowień fundamentalnych, być może ich zmiany w ogóle nie są możliwe? Do 2014 roku taką myśl na Litwie potraktowano by jako herezję, gdyż jeśli patrzy się tylko na tekst ${ }^{3}$ Konstytucji, może się wydawać, że dowolne jej postanowienie może być zmienione, chociaż w różny sposób. Nawet fundamentalne postanowienie zawarte w 1 artykule Konstytucji, które stanowi, że państwo litewskie jest niepodległą republiką demokratyczną, może być zmienione na drodze referendum, jeśli opowie się za

${ }^{1}$ Postanowienie Sądu Konstytucyjnego Republiki Litewskiej z 24 stycznia 2014 r. w sprawie ustawy o zmianie artykułu 125 Konstytucji. Tekst postanowienia w języku angielskim: http://www.lrkt.lt/dokumentai/2014/2014-01-24_KT2-N1_ruling.htm/.

${ }^{2}$ Postanowienie Sądu Konstytucyjnego Republiki Litewskiej z 11 lipca 2014 r. w sprawie trybu organizacji referendów. Tekst postanowienia w języku angielskim: http://www.lrkt.lt/ dokumentai/2014/2014-07-11_KT36-N10_ruling.htm/.

${ }^{3}$ Angielski tekst Konstytucji Republiki Litewskiej z 25 października 1992 r., http:// www3.Irs.lt/home/Konstitucija/Constitution.htm/. 
tym nie mniej niż 3/4 obywateli Litwy posiadających prawo wyborcze (artykuł 148 ustęp 1 Konstytucji).

Zatem celem tego artykułu jest analiza problematyki wieczystych postanowień (ang. eternity clauses) konstytucyjnych: dokonanie ich określenia, wyróżnienie typów, wyjaśnienie ich znaczenia.

\section{Pojęcie wieczystych postanowień konstytucyjnych}

Wieczyste postanowienia (eternity clauses) konstytucyjne można określić jako postanowienia konstytucyjne ${ }^{4}$ lub zasady konstytucyjne ${ }^{5}$, które nie mogą zostać zmienione ${ }^{6}$. Dlatego postanowienia te stanowią swego rodzaju przeszkodę lub znak „Stop” dla zmian konstytucji. Jakakolwiek poprawka naruszająca te postanowienia sama przez się byłaby antykonstytucyjna i nieważna ${ }^{7}$. Takie niezmienne, czyli wieczyste, postanowienia mogą mieć charakter formalny, tzn. są wyraźnie wpisane w tekście konstytucji, bądź implicytny (wnioskowane z ogółu regulacji konstytucyjnych). Eksplicytne postanowienia wieczyste są zawarte w blisko 35\% światowych konstytucji (tj. w 71) ${ }^{8}$. Jednak równie ważne jest, aby zauważyć sądowe (jurysdykcyjne) wieczyste postanowienia konstytucyjne, tzn. implicytne postanowienia wieczyste, które są wykrywane w ramach wykładni konstytucji, doko-

\footnotetext{
${ }^{4}$ Na przykład Konstytucja Armenii: „Artykuły 1, 2 i 114 Konstytucji nie mogą być zmieniane".

${ }^{5}$ Na przykład Konstytucja Norwegii: „Poprawka nigdy nie może być sprzeczna z zasadami określonymi w niniejszej Konstytucji, lecz powinna dotyczyć tylko zmian konkretnych postanowień, poprzez które nie ulega zmianie duch Konstytucji, i trzeba, by za zmianą taką opowiedziały się dwie trzecie (2/3) członków Stortingu". Jednak zdaniem Komisji Weneckiej (zob. przyp. 6), w ostatnim stuleciu postanowienie to nie pełniło funkcji ograniczającej i w systemie konstytucyjnym Norwegii dokonano wielu ważnych zmian.

${ }^{6}$ Takie określenie jest oparte na sprawozdaniu Komisji Weneckiej o poprawkach konstytucji (zob.: http://www.e-democracy.md/files/elections/report-constitutional-amendment12-12-2009-en.pdf/).

${ }^{7}$ Wieczyste postanowienia konstytucyjne mogą zapewnić ochronę wielu rzeczy, jak na przykład: przestrzegania dogmatów islamu (Afganistan, Iran), świeckiego charakteru państwa (Burundi, Turcja), roli języka arabskiego jako narodowego i urzędowego (Algieria), równego prawa każdego stanu do równych praw wyborczych w Senacie (Stany Zjednoczone Ameryki) lub formy rządów - republiki (Francja, Turcja i in.), istotnych elementów państwowości i ustroju konstytucyjnego - niepodległości, jednolitości terytorium, gwarancji praw i wolności człowieka (Ukraina) i in.

${ }^{8}$ Projekt porównujący konstytucje, przygotowany przez Zachary'ego Elkinsa, Tomasa Ginsburga i Jamesa Meltona. Zob.: https://www.constituteproject.org/search/topics\#? key=unamend/.
} 
nywanej przez sądy konstytucyjne lub inne instytucje sprawujące kontrolę konstytucyjności.

Należy zwrócić uwagę na ścisły związek pomiędzy wieczystymi postanowieniami konstytucyjnymi a tożsamością konstytucyjną. Pojęcie tożsamości konstytucyjnej nie ma jednolitej definicji, jednak przynajmniej częściowo można oprzeć się w tej kwestii na ideach Gary'ego Jeffreya Jacobsohna; mówi on o konkretnej historii narodu, jego wartościach i dążeniach, jako o czymś, co określa tożsamość konstytucyjną narodu. Zdaniem G. J. Jacobsohna, chociaż tożsamość konstytucyjna jest kategorią dynamiczną i stale rozszerzaną, równocześnie wymaga ona ochrony przed zniszczeniem. Dlatego gdy naród, który podjął się odpowiedzialności za konstytucyjność, dąży do zharmonizowania różnych elementów (na przykład takich, które pojawiły się w wyniku oddalenia się zapisanych zobowiązań konstytucyjnych i zmiennego środowiska politycznego, ekonomicznego bądź dotyczącego poglądów wartościowych), zazwyczaj pozostaje wierny fundamentalnym strukturom, składającym się na jego tożsamość konstytucyjną. To oznacza, że sąd konstytucyjny ma prawo anulować poprawkę konstytucyjną przyjętą zgodnie z wymogami proceduralnymi określonymi w konstytucji, jeśli poprawka ta w sposób istotny narusza tożsamość konstytucyjną narodu'.

Idee G. J. Jacobsohna są atrakcyjne przez to, że wieczyste postanowienia konstytucyjne powinny być rozumiane jako zapewniające ochronę istoty fundamentalnych zasad konstytucyjnych i równocześnie pozostawiające miejsce dla stale rozszerzanej wykładni tych zasad. Jak podkreśla Komisja Wenecka ${ }^{10}$, takie, uznawane najczęściej za niezmienne, zasady, jak: „,suwerenność”, „demokracja”, „republikanizm”, „federalizm” czy „prawa podstawowe”, z biegiem czasu były stale rozszerzane zarówno na poziomie międzynarodowym, jak i narodowym, i będą rozszerzane $w$ przyszłości $\mathrm{i}^{11}$. Dlatego prawidłowo rozumiane wieczyste postanowienia konstytucyjne należy traktować nie jako narzucające niezmienny i prowadzący w ślepy zaułek konstytucjonalizm, lecz jako niepozwalające dokonywać zmian, które by naruszyły samą istotę odpowiednich zasad konstytucyjnych (samego konstytucjonalizmu).

${ }^{9}$ Constitutional Identity by Gary Jeffrey Jacobsohn, http://www.lawcourts.org/LPBR/ reviews/jacobsohn0311.htm/.

${ }^{10}$ Europejska Komisja na rzecz Demokracji przez Prawo (Komisja Wenecka) - organ doradczy Rady Europy w dziedzinie konstytucjonalizmu. Rolą Komisji Weneckiej jest „świadczenie konsultacji prawnych" dla państw członkowskich i, przede wszystkim, udzielanie pomocy państwom, które dążą do harmonizacji swych struktur prawnych i instytucjonalnych z europejskimi standardami oraz międzynarodowym doświadczeniem w dziedzinie demokracji, praw człowieka i zwierzchności prawa.

${ }^{11}$ Sprawozdanie Komisji Weneckiej o poprawkach konstytucji, zob. przyp. 6. 


\section{Typy wieczystych postanowień konstytucyjnych}

Inny aspekt, który warto poruszyć przy rozpatrywaniu związku pomiędzy wieczystymi postanowieniami a tożsamością konstytucyjną - to rodzaje wartości uznawanych za niezmienne (niezniszczalne). Na ich podstawie można dokonać podziału odpowiednich typów wieczystych postanowień konstytucyjnych.

Porównawcze prawo konstytucyjne ujawnia, że postanowienia wieczyste mogą mieć zastosowanie w dążeniu do zapewnienia ochrony dwóch rodzajów wartości dotyczących tożsamości konstytucyjnej narodu. Na pierwszą grupę składają się takie uniwersalne wartości, jak demokracja, przyrodzone i niezbywalne prawa człowieka oraz zwierzchność prawa (państwo prawne). Inna grupa to konkretne wartości, odzwierciedlające takie konkretne cechy tożsamości konstytucyjnej określonego narodu, jak na przykład: federalizm, rola religii w konkretnym społeczeństwie czy określone zasady podziału władz. Na Litwie taką konkretną cechą, opartą na historycznej przeszłości, jest konstytucyjna zasada orientacji geopolitycznej państwa litewskiego, obejmująca konstytucyjny zakaz udziału w politycznych, wojskowych, ekonomicznych lub innych związkach czy wspólnotach państw tworzonych na fundamencie dawnego ZSRR ${ }^{12}$.

Zasada ta stanowi dobrą ilustrację dla wyróżnienia jeszcze jednego typu wieczystych postanowień konstytucyjnych; możliwe są wieczyste postanowienia konstytucyjne de iure (które w ogóle nie mogą być zmienione) i de facto. Komisja Wenecka zaznaczyła, że postanowienia konstytucyjne, do zmiany których stosuje się szczególnie trudne wymogi, można uznać za niezmienne de facto $^{13}$. Właśnie do tego typu wieczystych postanowień konstytucyjnych zaliczyć należy wspomniany zakaz udziału Republiki Litewskiej we wschodnich związkach postsowieckich, gdyż można go zmienić tylko na drodze referendum kwalifikowaną większością 3/4 głosów wszystkich obywateli Litwy posiadających czynne prawo wyborcze ${ }^{14}$.

${ }^{12}$ Zakaz ten ustanowiony jest w Akcie Konstytucyjnym „W sprawie nieprzyłączania się Republiki Litewskiej do wschodnich związków postsowieckich”, który stanowi część składową Konstytucji.

${ }^{13}$ Sprawozdanie Komisji Weneckiej o poprawkach konstytucji, zob. przyp. 6.

${ }^{14}$ Jak zaznaczył Sąd Konstytucyjny Republiki Litewskiej w postanowieniach z 24 stycznia 2014 r. i z 11 lipca 2014 r. (zob. przyp. 1 i 2), postanowienia Aktu Konstytucyjnego „W sprawie nieprzyłączania się Republiki Litewskiej do wschodnich związków postsowieckich” mogą zostać zmienione tylko w takim samym trybie, jaki został określony w artykule 2 Ustawy Konstytucyjnej „O państwie litewskim” (tzn. tylko na drodze referendum większością 3/4 głosów obywateli Republiki Litewskiej posiadających czynne prawo wyborcze), gdyż opierają się one na tym samym oświadczeniu woli suwerennego narodu, jak i ustawa „0 państwie litewskim”. 
Dychotomia wieczystych wartości, choć nie absolutna, gdyż „uniwersalne i konkretne" wartości są w sposób nieunikniony ze sobą powiązane, może być rozumiana jako tworząca podstawę dyskusji o równowadze stabilności i elastyczności konstytucji. W niniejszym artykule omówiona zostanie tylko pierwsza kategoria, tj. postanowienia wieczyste, chroniące uniwersalne wartości, gdyż wartości te mają największą wagę dla europejskiej tożsamości konstytucyjnej i porządku publicznego.

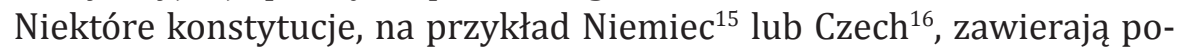
stanowienia, które explicite głoszą, że demokratyczna forma rządów jest niezmienna. Inne konstytucje (na przykład Ukrainy, Kosowa) zakazują dokonywania takich poprawek Konstytucji, które by zawęziły gwarancje praw i wolności człowieka. Oczywiste jest, że ponieważ „demokracja i poszanowanie praw i podstawowych wolności człowieka są od siebie nawzajem zależne i siebie nawzajem uzupełniają" ${ }^{\prime 1}$, takie postanowienia są nieodłącznie związane z dążeniem do ochrony istoty demokracji. Istnieje jednak wiele konstytucji demokratycznych, które nie zawierają eksplicytnych postanowień wieczystych. Dlatego może powstać pytanie, czy takie konstytucje należy postrzegać jako zezwalające na całkowitą eliminację demokratycznej formy rządów i (lub) umożliwiające, choćby teoretycznie, poważną ingerencję w podstawowe prawa. Wydaje się, że odpowiedź na to pytanie powinna być negatywna, gdyż konstytucje demokratyczne powinny być tłumaczone jako utwierdzające implicytne postanowienia wieczyste, zapewniające ochronę istoty demokracji.

\section{Znaczenie wieczystych postanowień konstytucyjnych}

Zatem dlaczego wieczyste postanowienia są konieczne? Można zacząć od sprawozdania Komisji Weneckiej o poprawkach konstytucji, w którym konstatuje, że „niezmienność jest skomplikowanym i możliwie kontrowersyjnym środkiem konstytucyjnym, który powinien być stosowany ostrożnie i przeznaczony tylko dla podstawowych zasad ustroju demokratycznego"18.

${ }^{15}$ Artykuł 20 Konstytucji Niemiec: „1. Republika Federalna Niemiec jest demokratycznym i socjalnym państwem federalnym. 2. Cała władza zwierzchnia pochodzi od narodu. Naród sprawuje władzę przez wybory i głosowania oraz przez uprawnione organy władzy ustawodawczej, wykonawczej i sądowniczej".

${ }^{16}$ Artykuł 9 ustęp 2 Konstytucji Czech: „Zmiany ingerujące w istotę demokratycznego państwa prawa są niedopuszczalne".

${ }^{17}$ Światowa Konferencja Praw Człowieka, deklaracja wiedeńska i program działań, część 8.

${ }^{18}$ Sprawozdanie Komisji Weneckiej o poprawkach konstytucji, zob. przyp. 6. 
Zatem Komisja Wenecka nie neguje ewentualnej użyteczności niezmienności dla ochrony podstawowych wartości demokratycznych.

Tymczasem argumenty, przy pomocy których podkreśla się rzekome ograniczenie suwerenności narodu poprzez zakaz zmiany konstytucji, nie są przydatne $\mathrm{w}$ ramach krytyki koncepcji wieczystych postanowień konstytucyjnych, zapewniających ochronę podstawowych wartości prawdziwej demokracji. Konstytucja nie powinna stać się narzędziem „demokratycznego samobójstwa”. Właśnie postanowienia zakazujące takich zmian konstytucji, które w istocie zniszczyłyby państwo prawne i demokrację, zniweczyłyby przyrodzone prawa człowieka, stanowią gwarancję suwerenności oraz demokratycznego samostanowienia narodu, jakkolwiek paradoksalnie to zabrzmi. Gdyby demokracja została zniesiona, choćby w sposób formalnie demokratyczny (powiedzmy - na drodze referendum), nie byłaby już możliwa dalsza realizacja suwereności i samostanowienia narodu ${ }^{19}$. Przykłady reżimów totalitarnych bądź autorytarnych pod tym względem są oczywiste. Dlatego wieczyste postanowienia konstytucyjne zapewniające ochronę uniwersalnych wartości należy, przede wszystkim, postrzegać jako ważne narzędzie demokracji, umożliwiające jej obronę.

Inny argument na rzecz wieczystych postanowień konstytucyjnych zapewniających ochronę demokratycznej formy rządów dotyczy szerszego kontekstu międzynarodowego rozwoju. Zobowiązania wobec demokracji i usiłowania szerzenia demokracji stanowią częsty temat zarówno na poziomie uniwersalnym, jak i regionalnym. Przykładowo, preambuła Traktatu Północnoatlantyckiego ${ }^{20}$ stanowi, że strony niniejszego traktatu „zobowiązują się ochraniać wolność, wspólne dziedzictwo i cywilizacje swych narodów, oparte na zasadach demokracji, wolności jednostki i rządów prawa". Zobowiązanie krzewienia wartości demokratycznych przyjmuje na siebie każdy kraj przyłączający się do Rady Europy i Unii Europejskiej. Takie zobowiązania wraz z tworzonymi międzynarodowymi standardami wynoszą podstawowe zasady demokracji na poziom ponadpaństwowy.

To, że wieczyste postanowienia konstytucyjne mają bronić demokracji i są oparte na wartościach ponadpaństwowych, w Traktacie Lizbońskim wyraźnie określił Federalny Trybunał Konstytucyjny Niemiec: „Dzięki temu, co nazywamy wieczną gwarancją, Ustawa Zasadnicza, z jednej strony, reaguje na doświadczenie historyczne, dotyczące powolnego lub nagłego rozpadu istoty fundamentalnego ustroju demokratycznego. Z drugiej strony jednak, wyraźnie określa, że Konstytucja Niemiec, szczególnie uwzględniając międzynarodowe zmiany po powstaniu Narodów Zjednoczonych, posiada uniwersalną podsta-

${ }^{19} \mathrm{~W}$ związku z tym można mówić o zmodyfikowanym „paradoksie niewolnika” Johna Stuarta Milla, zgodnie z którym zasada wolności nie może wymagać, by osoba miała wolność wyboru niebycia wolną.

${ }^{20}$ Zob.: http://nato.int/cps/en/natohq/official_texts_17120.htm?/. 
wę, której prawo pozytywne zmienić nie może"21. Zatem Trybunał Konstytucyjny Niemiec trzyma się idei, że fundamentalne demokratyczne wartości konstytucyjne, chronione przez wieczyste postanowienia konstytucyjne, powinny być rozumiane jako konstytucyjne metanormy, regulujące, do którego momentu i w jakiej skali możliwa jest zmiana konstytucji.

W tym kontekście można także mówić o pewnym upodobnieniu się (konwergencji) narodowych tożsamości konstytucyjnych, opartym na demokracji, przesądzającym o kształtowaniu się międzynarodowych tożsamości o szerszej skali. Na ten temat szczególnie szeroko dyskutuje się w aspekcie tak zwanej „tożsamości (konstytucyjnej) Europy”. Ponieważ Europa (włącznie z Unią Eurpopejską i Radą Europy) nie posiada konstytucji sensu stricto, jej tożsamość konstytucyjna oparta jest na upodobnieniu się wartości umocowanych w narodowych systemach konstytucyjnych. Taka oparta na upodobnieniu się koncepcja jest oczywista, na przykład w Deklaracji Tożsamości Europejskiej ${ }^{22}$ z 1973 roku, w której dziewięć państw ówczesnej Wspólnoty Europejskiej stwierdziło, że „podzielając ten sam pogląd, [...] są zdecydowane bronić zasad demokracji przedstawicielskiej, zwierzchności prawa, sprawiedliwości socjalnej [...] i poszanowania praw człowieka. Są to fundamentalne elementy tożsamości europejskiej”. Można oprzeć się również na artykule 2 Traktatu o Unii Europejskiej ${ }^{23}$, który stanowi, że „Unia opiera się na wartościach poszanowania godności osoby ludzkiej, wolności, demokracji, równości, państwa prawnego, jak również poszanowania praw człowieka, w tym praw osób należących do mniejszości. Wartości te są wspólne państwom członkowskim [...]". Pojęcie upodobnienia się odzwierciedla się również w ustępie 3 artykułu 6 Traktatu o Unii Europejskiej, w którym podstawowe prawa, gwarantowane przez Europejską Konwencję o Ochronie Praw Człowieka, określa się jako ogólne zasady prawa unijnego, wynikające ze wspólnych dla państw członkowskich tradycji konstytucyjnych. Wreszcie, bez wątpienia, warto wspomnieć dobrze znane dictum Europejskiego Trybunału Praw Człowieka: „Demokracja, niewątpliwie, jest fundamentalną cechą europejskiego porządku publicznego"24.

${ }^{21}$ BVerfG, 2 BvE 2/08, 2009.06.30: http: //www.bverfg.de/entscheidungen/es20090630 _2bve000208en.html/. W postanowieniu tym Sąd konstatował, że „zgodnie z trybem przewidzianym z Ustawie Zasadniczej, treść określonych w artykule 20 Ustawy Zasadniczej strukturalnych zasad państwa, tzn. demokracji, zwierzchności prawa, zasady państwa socjalnego, republiki, państwa federacyjnego, jak również elementarnych podstawowych praw, niezbędnych dla zapewnienia poszanowania dla godności człowieka, w żaden sposób nie mogą być zmienione ze względu na swoją główną cechę".

${ }_{22}$ Zob.: http://www.cvce.eu/content/publication/1999/1/1/02798dc9-9c69-4b7d-b2c9-f03a8db7da32/publishable_en.pdf/.

${ }^{23}$ Redakcje ujednolicone Traktatu o Unii Europejskiej i Traktatu o funkcjonowaniu Unii Europejskiej, „Dziennik Urzędowy” C 326, 2012.10.26, s. 1-390.

24 Loizidou przeciwko Turcji, pkt 75 i n. 
Wiadomo, pojęcie demokracji jako wspólnej wartości nie ogranicza się tylko do przestrzeni Europy, gdyż słusznie można mówić, na przykład, o wspólnych wartościach regionu północnoatlantyckiego. We wspomnianej Deklaracji Tożsamości Europejskiej uznano wspólne wartości i dążenia, oparte na wspólnym dziedzictwie Europy i Stanów Zjednoczonych Ameryki.

To oznacza, że można mowić o wspólnym międzynarodowym, a przynajmniej europejskim (i transatlantyckim), interesie zapewnienia ochrony podstawowych wartości demokratycznych. Pod tym względem warto raz jeszcze oprzeć się na Komisji Weneckiej. W wytycznych dla narodowych referendów konstytucyjnych ${ }^{25}$ zaleca ona, aby teksty poddawane głosowaniu w referendum konstytucyjnym odpowiadały istotnym ograniczeniom reformy konstytucyjnej (wewnętrznym i zewnętrznym) i nie były sprzeczne z prawem międzynarodowym lub zasadami statutu Rady Europy (demokracji, praw człowieka i zwierzchności prawa). Teksty sprzeczne z tymi istotnymi wymogami nie powinny być poddawane głosowaniu w referendum. Oczywiste jest, że takie rekomendacje oznaczają, iż nie powinno się konstytucyjnie przyznawać większości wyborców prawa do przyjęcia poprawek do konstytucji negujących wartości, które stanowią podstawę ordre public Europy.

Równocześnie należy podkreślić, że o konieczności bronienia ochrony podstawowych wartości demokratycznych przesądza sama demokratyczna tożsamość konstytucyjna narodu. Mówiąc słowami Ulricha K. Preussa, „wieczyste postanowienia” określają istotne elementy mitu założycielskiego. Innymi słowy, określają one polityczny podmiot zbiorowy „my, naród”. Zmiana „wieczystych” klauzul normatywnych zrujnowałaby wcieloną w konstytucji tożsamość politycznego podmiotu zbiorowego ${ }^{26}$.

\section{Zamiast wniosków: rola sądu konstytucyjnego}

Postrzegając wieczyste postanowienia konstytucyjne jako podstawę i konieczny gwarant demokratycznej tożsamości konstytucyjnej, można odważyć się na stwierdzenie, że wieczyste postanowienia, utwierdzające uniwersalne wartości demokratyczne, są charakterystyczne dla konstytucji wszystkich państw demokratycznych. Mówiąc inaczej, brak eksplicytnych

${ }^{25}$ Wytyczne dla narodowych referendów konstytucyjnych przyjęte na 47. sesji plenarnej Komisji Weneckiej (6-7 lipca 2011 r., Wenecja), http://www2.ohchr.org/english/law/compilation_democracy/guidelines1.htm/.

${ }^{26}$ U. K. Preuss, The Implications of „Eternity Clauses”: the German Experience, „Israel Law Review" 2011, vol. 44, s. 445. 
postanowień, dotyczących niezmienności podstawowych zasad konstytucyjnych, sam przez się nie neguje istnienia implicytnych postanowień wieczystych, zapewniających ochronę raison d'être demokratycznych konstytucji. Odnaleźć takie postanowienia i odkryć ich treść powinien sąd konstytucyjny, który obarczono odpowiedzialnością za zapewnienie zwierzchności konstytucji w państwie, a równocześnie za ochronę demokratycznego ustroju państwa oraz demokratycznej tożsamości konstytucyjnej. Wykrycia implicytnych wieczystych postanowień nie uznaje się za wykładnię konstytucji contra legem, gdyż bez wieczystych wartości uniwersalnych (przyrodzonych praw człowieka, demokracji i wolności) nie istniałaby konstytucja.

W tym kontekście należy podać przykład z orzecznictwa Sądu Konstytucyjnego Republiki Litewskiej. W postanowieniu ${ }^{27}$ z 11 lipca 2014 r. Sąd stwierdził, że „przyrodzony charakter praw i wolności człowieka, demokracja i niepodległość państwa - to takie wartości konstytucyjne, które stanowią fundament Konstytucji jako umowy społecznej i opartego na niej wspólnego życia Narodu, samego państwa litewskiego". Dlatego „nikt nie może negować postanowień Konstytucji, utwierdzających te fundamentalne wartości konstytucyjne, gdyż oznaczałoby to negację istoty samej Konstytucji". Opierając sięna tych argumentach, Sąd Konstytucyjny podkreślił, że nawet przestrzegając ograniczeń dotyczących zmian Konstytucji, „nie można przyjąć poprawek do Konstytucji, znoszących przyrodzony charakter praw i wolności człowieka, demokrację lub niepodległość państwa"; inaczej interpretując Konstytucję, byłaby ona rozumiana jako tworząca przesłanki do zniesienia odnowionego przez ogłoszony w dniu 16 lutego 1918 r. Akt Niepodległości „niepodległego państwa litewskiego, opartego na demokratycznych podstawach" (innymi słowy, sama Konstytucja nie stanowi przesłanek do zniesienia umocowanych w akcie założycielskim państwa fundamentalnych wartości demokracji i niepodlegości). Zatem to postanowienie Sądu Konstytucyjnego odzwierciedla ideę, że prawo podmiotu zakładającego (Narodu) do zmiany konstytucji nie obejmuje prawa do stworzenia całkowicie nowej konstytucji, w której zostałyby zniesione uniwersalne wartości - demokracja, przyrodzone prawa człowieka i niepodległość państwa.

Dlatego też, gdyby została przyjęta decyzja o rezygnacji z podstawowych wartości prawdziwej demokracji, nawet gdyby decyzję taką poparła absolutna większość mieszkańców, powinno się ją traktować jako przyjętą poza granicami istniejącej demokratycznej struktury konstytucyjnej, co oznacza przyjęcie całkowicie nowej konstytucji i zrujnowanie istniejącej tożsamości konstytucyjnej. Byłoby to zabójcze dla rozwoju kraju, gdyż, powtarzając za Winstonem Churchillem, „demokracja jest najgorszą formą rządu, jeśli nie liczyć wszystkich innych, których próbowano".

${ }^{27}$ Zob. przypis 2 . 